\title{
Decolonizing Picture Recitation
}

\author{
Keywords \\ ArtScience, Erotic poetry, Decolonization, Picture Recitation, Rasa Theory.
}

Picture recitation is the art of storytelling in verse accompanied with a visual prop like a scroll painting or a tapestry. Numerous picture recitation practices were active in India but suffered during colonization by the British in many ways. The subtle Victorian censorship of the theme of erotic expressed in the religious narratives (which formed the bulk of the picture recitation genre), the erasure of orature as primitive, the relegation of picture recitation practices as folk art and the split between picture (object and props that can be displayed in museums) and recitation (performative aspects that could not be easily museumized) while stuffing European museums with colonial artifacts, have inflicted huge damage to the living traditions of picture recitation in India. My practice-led research seeks to decolonize picture recitation to undo these damages. Following Walter Mignolo's call to delink oneself from western hegemony, I seek to highlight (instead of European notions of beauty and aesthetics) classical Indian theories of affect (from circa $300 \mathrm{CE}$ ) that can produce aesthetic pleasure in the viewer. Thus using classical Indian Rasa theory as well as subversion, I create contemporary narratives for picture recitation using empirical facts from scientific research (Neuroscience, Microbiology, Phytochemistry and Meteorology) which are aided with visual props made by amalgamating aesthetics of medieval
Indian miniature painting as well as contemporary medical Illustration. A practice-led research is the only method to redeem the practice of picture recitation, just as the contemporary practice of neo-miniatures has rescued the genre of miniature paintings from the classification of oriental kitsch. By investing in erotic subject matter and orature as well as by reuniting picture and recitation, I hope to remove the adverse effects of colonization from some genres of Indian arts. Concretely my practice looks at contemporizing classical erotic Sanskrit poetry which has existed since 1000 $\mathrm{BC}$ by composing erotic poetry incorporating scientific research and creating compositions of image and text as was once found in medieval Indian miniatures. The second approach looks at reviving picture recitation using a classical Indian archetype of a female heroine who goes out to meet her lover braving grave dangers and contemporizing it with reading through neuroscientific lenses. Via the practice of picture recitation, I discover my bodily memories surfacing during the performance, the role of breath in voice, how image, text, voice and performance influence each other iteratively and how affect is transfered via the performance to the viewer. Through practice, I establish a wider field for newcomers with greater vigour and validity than simply echoing a theoretical call for decolonization. 